\title{
Cold related mortalities and protection against cold in Yakutsk, eastern Siberia: observation and interview study
}

\author{
G C Donaldson, S P Ermakov, Y M Komarov, C P McDonald, W R Keatinge
}

\section{Department of Physiology, Basic Medical Sciences, Queen Mary and Westfield College, University of London, London E1 4NS \\ G C Donaldson, senior research associate \\ W R Keatinge, emeritus professor of physiology \\ Public Health Research Institute, Russian Ministry of Health, Moscow 127254, Russia Y M Komarov, director general S P Ermakov, principal researcher \\ McDonald \\ Research, \\ Peckwater, \\ Camberley, Surrey \\ GU15 2LY \\ C P McDonald, \\ director \\ Correspondence to: Professor Keatinge w.r.keatinge@ qmw.ac.uk}

BMJ 1998;317:978-82

\begin{abstract}
Objective To assess how effectively measures adopted in extreme cold in Yakutsk control winter mortality. Design Interviews to assess outdoor clothing and measure indoor temperatures; regressions of these and of delayed cause-specific mortalities on temperature.

Setting Yakutsk, east Siberia, Russia. Subjects: All people aged 50-59 and 65-74 years living within $400 \mathrm{~km}$ of Yakutsk during 1989-95 and sample of 1002 men and women who agreed to be interviewed.
\end{abstract}

Main outcome measures Daily mortality from all causes and from ischaemic heart, cerebrovascular, and respiratory disease.

Results Mean temperature for October-March $1989-95$ was $-26.6^{\circ} \mathrm{C}$. At $10.2^{\circ} \mathrm{C}$ people wore 3.30 (95\% confidence interval 3.08 to 3.53 ) layers of clothing outdoors, increasing to 4.39 (4.13 to 4.66; $\mathrm{P}<0.0001$ ) layers at $-20^{\circ} \mathrm{C}$. Thick coats, often of fur, replaced anoraks as temperature fell to $-48.2^{\circ} \mathrm{C} .82 \%$ of people went out each day when temperatures were $10.2^{\circ} \mathrm{C}$ to $-20^{\circ} \mathrm{C}$, but below $-20^{\circ} \mathrm{C}$ the proportion fell steadily to $44 \%(35 \%$ to $53 \%)$ at $-48.2^{\circ} \mathrm{C}$ $(\mathrm{P}<0.001)$, and overall shivering outdoors did not increase. Living room temperature was 17.9 (17.2 to $18.5)^{\circ} \mathrm{C}$ at $10.2^{\circ} \mathrm{C}$ outdoors, $19.6(18.8 \text { to } 20.4)^{\circ} \mathrm{C}$ at $-20^{\circ} \mathrm{C}$, and $19.1(18.6 \text { to } 19.6)^{\circ} \mathrm{C}$ at $-48.2^{\circ} \mathrm{C}$. Mortality from all causes and from ischaemic heart and respiratory disease was unaffected by the fall in temperature. Mortality from respiratory disease (daily deaths per million) rose from 4.7 (4.3 to 5.1) to 5.1 (4.4 to 5.7) $(\mathrm{P}=0.03)$, but this was offset by a fall in deaths from injury.

Conclusions People in Yakutsk wore very warm clothing, and in extremely cold weather stayed indoors in warm housing, preventing the increases in mortality seen in winter in milder regions of the world. Only respiratory mortality rose, perhaps because of breathing cold air.

\section{Introduction}

Deaths from ischaemic heart, cerebrovascular, and respiratory disease and from all causes rise as temperature falls below $18^{\circ} \mathrm{C}$ in Europe $^{1}$ and other temperate regions, ${ }^{2-4}$ particularly those with poor outdoor clothing and home heating. ${ }^{1}$ However, mortality increased only at temperatures below $0^{\circ} \mathrm{C}$ in the west Siberian city of Yekaterinburg, where clothing and home heating prevented cold stress above $0^{\circ} \mathrm{C} .{ }^{5}$ Mortality from ischaemic heart disease increases rapidly after cold weather, ${ }^{6}$ probably because of haemoconcentration induced by cold, ${ }^{78}$ slower thrombogenic effects of respiratory infections, ${ }^{9}$ and rapid reflex effects of cold. ${ }^{10}{ }^{11}$ It remains uncertain whether appropriate clothing can prevent deaths below $0^{\circ} \mathrm{C}$ as respiratory mortality might be promoted not only by general body chilling but by direct cooling of the respiratory tract. ${ }^{12}$

We report protection taken against cold and death rates in winter in Yakutsk in eastern Siberia. Yakutsk is the world's coldest city, ${ }^{13}$ with temperatures averaging only $-26.6^{\circ} \mathrm{C}$ during October to March compared with $-6.8^{\circ} \mathrm{C}$ in Yekaterinburg ${ }^{5}$ and $-2.8^{\circ} \mathrm{C}$ in northern Finland.

\section{Methods}

Data on mortality, population, and climate

We analysed daily deaths among people living in districts within $400 \mathrm{~km}$ of Yakutsk and in the city itself for 1989-95. Deaths were analysed separately for age groups 50 to 59 and 65 to 74 years and for men and women. Deaths in the seven days before and after the end of each year were excluded because consistency checks showed a fall in recorded deaths in the final few days of each year. This occurred because some deaths were not recorded until after the start of the next year and were not entered in the previous year's data. We estimated the region's mean population for the study period from census data. There were 44656 men and 46680 women aged 50 to 59 and 9087 men and 16653 women aged 65 to 74 ; the total population was 545771 men and 541463 women. Annual plots showed that although deaths per million population rose in successive years, the relation of mortality to temperature did not change significantly with time or differ between the age and sex groups studied; the years and groups were therefore pooled for subsequent analysis. Daily mean temperatures in Yakutsk were calculated from four hourly measurements.

\section{Survey of cold exposure}

The survey was commissioned from Marketing Information Center, a Russian-Finnish company associated with Gallup. Interviews were conducted with 1002 people in Yakutsk and surrounding regions: 258 men and 265 women aged 50-59, and 217 men and 262 women aged 65-74. Interviews were conducted by trained interviewers after midday in the interviewees' main living room. Interviewers used the same questionnaire as in the Yekaterinburg study. ${ }^{5}$ Room temperature was measured during the interview with $1^{\circ} \mathrm{C}$ Thermax temperature strips (Thermographic Measurements, Burton) placed at a height of $0.5 \mathrm{~m}$ to $1.2 \mathrm{~m}$ on furniture and away from sources of heat. Questions were asked about indoor heating, outdoor clothing, physical activity, shivering during the first outdoor excursion of the day of more than 10 minutes, and the number of such excursions in the previous 24 hours.

Interviewees were selected by a two stage process to be representative of population by social group and by urban or rural site, with rules to prevent clustering. ${ }^{14}$ Interviews were arranged by visiting the home or by making a telephone call to identify someone in the 


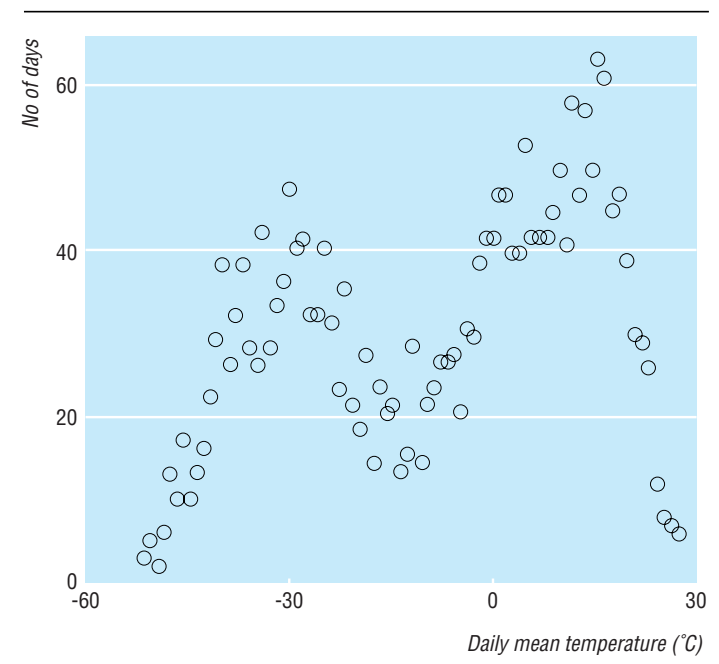

Fig 1 Frequency distribution of mean daily temperatures in Yakutsk, eastern Siberia, 1989 to 1995

right age group who was willing to take part. Interviews were spread evenly over all days of the week from 15 September 1996 to the end of February 1997 and were subject to quality control. ${ }^{5}$ Interviews on 5-9 February were attended by three of the authors (GCD, CPMcD, WRK).

The number of layers of clothing worn was calculated as the total area of clothing expressed as a fraction of body surface area. ${ }^{5}{ }^{15}$ Linear and logit regression were used to determine whether normally and binary distributed variables changed significantly with temperature and to predict the variables at a given temperature.

\section{Regression analysis}

We calculated linear regression coefficients for the daily number of deaths in relation to mean daily temperature using Stata 4 software; generalised linear modelling was used with identity link function, and a Poisson distribution was assumed. ${ }^{16}$ No lag was used for deaths from injury, but we used a lag on temperature of two days for ischaemic heart disease, five days for cerbrovascular disease, 12 days for respiratory disease, and three days for all causes; these delays give the highest regression coefficients. ${ }^{6}$ As only one death from influenza was recorded we did not adjust for influenza.

Values and proportions given are means $(95 \%$ confidence intervals) predicted from regressions unless stated otherwise. The regressions of survey variables were calculated separately for the range $10.2^{\circ} \mathrm{C}$ to $-20^{\circ} \mathrm{C}$ and for $-20^{\circ} \mathrm{C}$ to $-48.2^{\circ} \mathrm{C}$ because discontinuity was generally evident at or near $-20^{\circ} \mathrm{C}$; all the linear regression coefficients calculated for non-binary survey variables were significantly different for the two ranges. Estimates given for $-20^{\circ} \mathrm{C}$ are based on the $10.2^{\circ} \mathrm{C}$ to $-20^{\circ} \mathrm{C}$ regression, except when this was not significant, when the $-20^{\circ} \mathrm{C}$ to $-48.2^{\circ} \mathrm{C}$ regression was used. For mortality data, in which no discontinuity was evident at $-20^{\circ} \mathrm{C}$, the whole of the temperature range was used $\left(10.2\right.$ to $\left.-48.2^{\circ} \mathrm{C}\right)$. Autoregressive terms were not included in the regression analyses as it was not intended to exclude the effects of factors such as upper respiratory infections in winter, which would
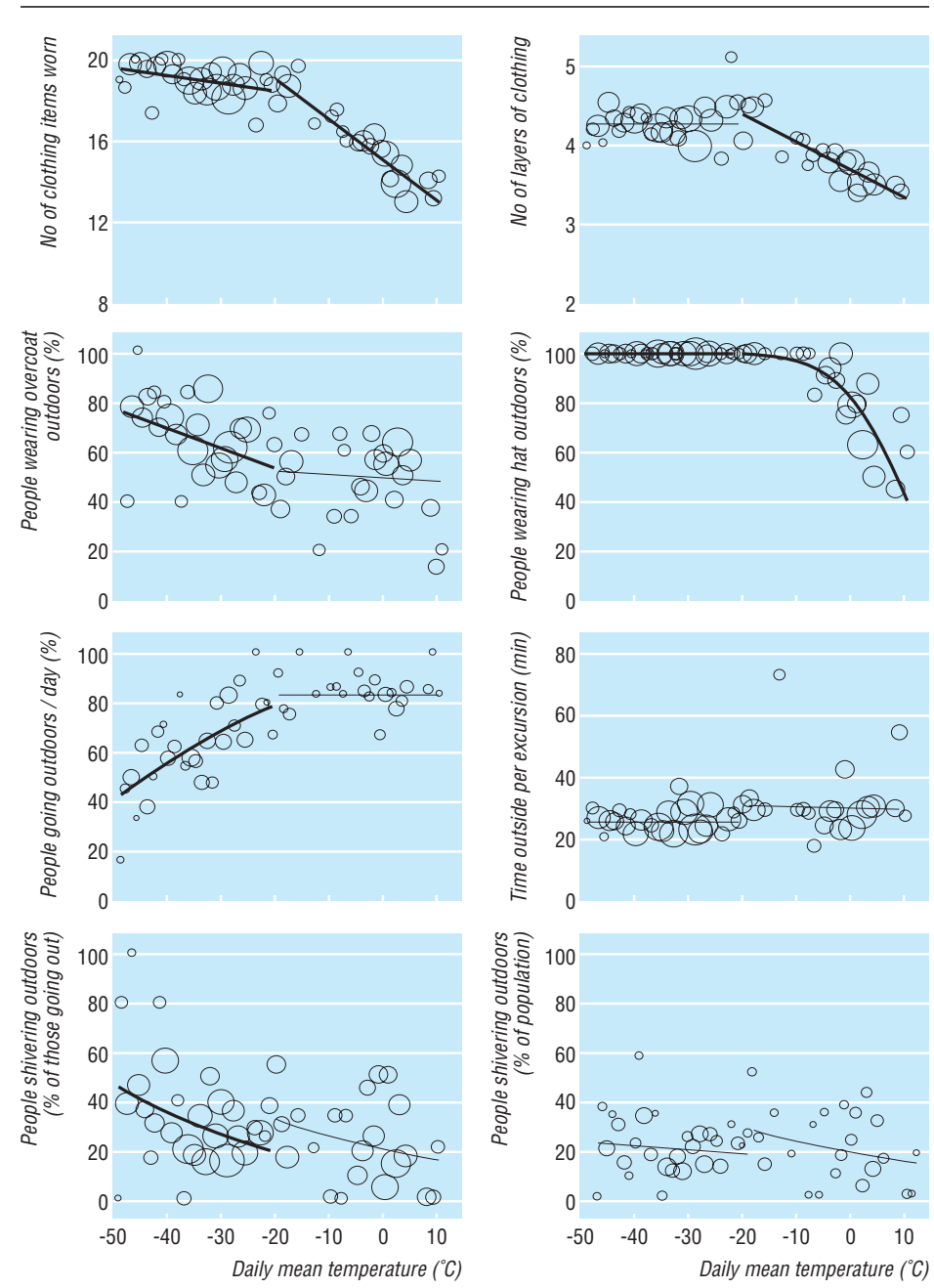

Fig 2 Regression analysis of numbers of items and layers of clothing worn outside, percentage wearing hats and overcoats, percentage going outdoors each day and duration of excursions, and percentage reporting shivering while outdoors by mean daily temperature. Thick line indicates $\mathrm{P}<0.05$, thin line $\mathrm{P}>0.05$

be minimised by such a term. However, the significance of our mortality-temperature relations was not altered when we recalculated with a one day autoregressive term, with or without a further trend term. For graphs, data were averaged at $1^{\circ} \mathrm{C}$ intervals.

\section{Results}

Mean daily temperature varied between $28.0^{\circ} \mathrm{C}$ and $-51.5^{\circ} \mathrm{C}$ during 1989 to 1995 (fig 1), with a mean temperature in winter (October to March) of $-26.6^{\circ} \mathrm{C}$,

Values (95\% confidence interval) for outdoor clothing and activity and indoor heating according to outdoor temperature

\begin{tabular}{lccc} 
Values predicted from regression & $\mathbf{- 4 8 . 2} \mathbf{}^{\circ} \mathbf{C}$ & $-\mathbf{2 0 . 0}$ & $\mathbf{1 0 . 2}{ }^{\circ} \mathbf{C}$ \\
\hline No of items of clothing & $19.6(19.0$ to 20.1$)$ & $19.1(18.4$ to 19.8$)$ & $12.9(12.3$ to 13.6$)$ \\
\hline No of layers of clothing & $4.26(4.04$ to 4.48$)$ & $4.39(4.13$ to 4.66$)$ & $3.30(3.08$ to 3.53$)$ \\
\hline$\%$ of people wearing anoraks & $25.1(16.4$ to 36.4$)$ & $46.6(35.6$ to 58.0$)$ & $48.9(36.7$ to 61.2$)$ \\
\hline$\%$ of people wearing overcoats & $75.8(64.7$ to 84.3$)$ & $52.9(41.5$ to 64.0$)$ & $50.0(37.7$ to 62.2$)$ \\
\hline$\%$ of people going out per day & $43.9(35.1$ to 53.0$)$ & $70.0(71.5$ to 84.9$)$ & $81.9(71.3$ to 89.1$)$ \\
\hline$\%$ of people going out who shivered & $45.3(33.1$ to 58.1$)$ & $18.8(12.2$ to 27.9$)$ & $15.2(8.7$ to 25.1$)$ \\
\hline Living room temperature $\left({ }^{\circ} \mathrm{C}\right)$ & $19.1(18.6$ to 19.6$)$ & $19.6(18.8$ to 20.4$)$ & $17.9(17.2$ to 18.5$)$ \\
\hline$\%$ with heated bedrooms & $73.8(65.4$ to 80.7$)$ & $62.9(53.5$ to 71.5$)$ & $56.2(44.7$ to 67.2$)$ \\
\hline
\end{tabular}


and mean wind speed of $4.5 \mathrm{~km} / \mathrm{h}$ (highest value $43.2 \mathrm{~km} / \mathrm{h}$ ). During the survey (14 September 1996 to 28 February 1997) temperature varied between $10.2^{\circ} \mathrm{C}$ and $-48.2^{\circ} \mathrm{C}$.

As temperature fell from $10.2^{\circ} \mathrm{C}$ to $-20^{\circ} \mathrm{C}$ the number of items of clothing worn outdoors increased by $48 \%(\mathrm{P}<0.001)$ and the number of layers of clothing increased by $33 \%(\mathrm{P}<0.001)$ (table, fig 2). As temperature fell from $-20^{\circ} \mathrm{C}$ to $-48.2^{\circ} \mathrm{C}$ the area of clothing worn outdoors did not increase significantly and the number of items increased by only $2 \%$ $(\mathrm{P}=0.013)$. However, overcoats progressively replaced anoraks; the percentage of people who wore anoraks outdoors fell by $21.5 \%(\mathrm{P}=0.025)$ and the percentage wearing overcoats increased by $22.9 \%(\mathrm{P}=0.016)$. Below $-20^{\circ} \mathrm{C}$ everyone wore a hat and gloves outdoors.

Personal observation suggested that hats and most overcoats and other outer clothing worn outdoors in the town at temperatures around $-35^{\circ} \mathrm{C}$ were made of fur or other thick material and covered the ears and often the sides of the face. The front of the face was not covered by clothing. Most people travelled by bus or on foot rather than by car.

The percentage of people who went outdoors in the 24 hours before interview did not change as temperature fell from 10.2 to $-20^{\circ} \mathrm{C}(254$ out of 308 $(82 \%)$ surveyed on days of these temperatures went out). Below $-20^{\circ} \mathrm{C}$ the percentage going out fell sharply to $44 \%$ at $-48.2^{\circ} \mathrm{C}(\mathrm{P}<0.001)$. The fall in temperature had no significant effect on the duration of outdoor excursions (average 26.5 (95\% confidence interval 25.2 to 27.8 ) minutes); the number of daily excursions by those who went out (3.2 (3.0 to 3.4)); or the proportion of outdoor excursions in which people stood still for at least two minutes $(24.2 \%, 160 / 660)$.

The percentage of people who shivered per outdoor excursion did not rise significantly as temperature fell to $-20^{\circ} \mathrm{C}$ but increased by $26.5 \%$ as temperature fell to $-48.2{ }^{\circ} \mathrm{C}(\mathrm{P}=0.004)$. The daily incidence of shivering outdoors among the total population surveyed, including those who did not go out, did not change as temperature fell, even below $-20^{\circ} \mathrm{C}$ as the fall in outdoor excursions was balanced by more frequent shivering among those who did go out.

As outdoor temperature fell from 10.2 to $-20^{\circ} \mathrm{C}$ living room temperature (fig 3) increased by $1.7^{\circ} \mathrm{C}$ to $19.6^{\circ} \mathrm{C}(\mathrm{P}=0.007)$; it then fell slightly $(\mathrm{P}=0.013)$ but was $19.1^{\circ} \mathrm{C}$ even at the lowest outdoor temperature of the survey, $-48.2^{\circ} \mathrm{C}$. The percentage of bedrooms directly heated for over an hour a night (ignoring indirect heating from nearby rooms) increased progressively as temperature fell $(\mathrm{P}=0.004)$ to $73.8 \%$ at $-48.2^{\circ} \mathrm{C}$.

Daily deaths rates (with total deaths in brackets) were 1.79 (4558) for ischaemic heart disease, 1.05 (2677) for cerebrovascular disease, 0.52 (1328) for respiratory disease, 0.14 (351) for accidental injury, and 7.66 (19 435) for all causes. Neither ischaemic heart disease nor cerebrovascular mortality increased significantly as temperature fell from 10.2 to $-48.2^{\circ} \mathrm{C}$ (fig 4). Mortality from respiratory disease increased from 4.69 (4.31 to 5.06) per million at $10.2^{\circ} \mathrm{C}$ to 5.07 (4.42 to 5.73) per million at $-48.2^{\circ} \mathrm{C}(\mathrm{P}=0.027)$. However, daily mortality from injuries fell from 1.33 (1.03 to 1.64) per million at $10.2^{\circ} \mathrm{C}$ to 0.82 (0.51 to 1.33$)$ per million at $-48.2^{\circ} \mathrm{C}(\mathrm{P}<0.001)$ and all cause mortality did not change.
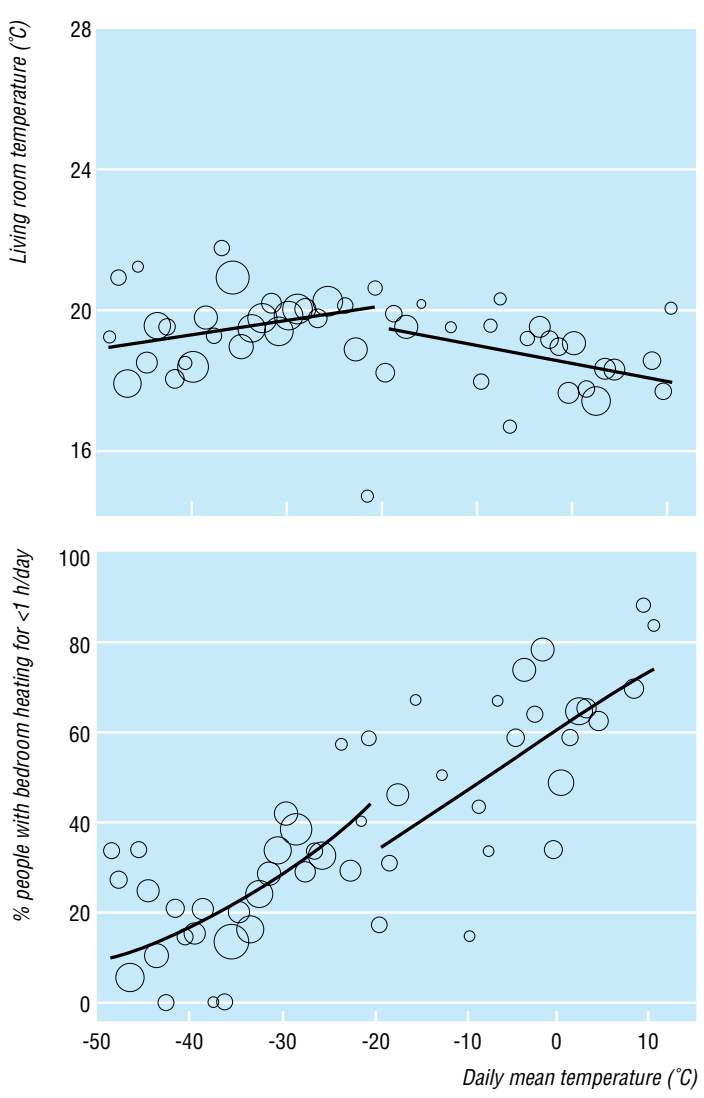

Fig 3 Regression analysis of temperatures in living room at time of interview and percentage with bedroom heated for less than 1 hour according to mean daily temperature. Thick line indicates $P<0.05$, thin line $P>0.05$

\section{Discussion}

The almost constant 4.26 layers of clothing worn outdoors in Yakutsk at $-20^{\circ} \mathrm{C}$ to $-48.2^{\circ} \mathrm{C}$ compares with only 3.67 layers worn in Yekaterinburg ${ }^{5}$ at temperatures of $-8^{\circ} \mathrm{C}$ to $-25^{\circ} \mathrm{C}$. This probably understates the difference in maximum insulation provided by outdoor clothing as outer clothing in Yakutsk generally consisted of fur or other thick material. Clothing therefore probably explains the fact that cold stress per outdoor excursion in Yakutsk, estimated from shivering, did not increase until the temperature fell below $-20^{\circ} \mathrm{C}$ whereas it increased below $0^{\circ} \mathrm{C}$ in Yekaterinburg. The other main behavioural adjustment in Yakutsk, a reduction of almost half in the number of people going out, was seen only below $-20^{\circ} \mathrm{C}$.

The living room temperatures in Yakutsk of $19.6^{\circ} \mathrm{C}$ at $-20.0^{\circ} \mathrm{C}$ outdoors and $19.1^{\circ} \mathrm{C}$ at $-48.2^{\circ} \mathrm{C}$ outdoors are unlikely to have resulted in appreciable indoor cold stress to a population equipped with warm clothing. The increase in frequency of bedroom heating as outdoor temperature fell will have tended to prevent cold stress at night.

Mortality from ischaemic heart disease, cerebrovascular disease, and all causes did not rise as temperatures fell to $-48.2^{\circ} \mathrm{C}$ in Yakutsk, which contrasts with findings in western Europe, where death rates rose as temperatures fell below $18^{\circ} \mathrm{C}$, and in Yekaterinburg, where they rose at temperatures below $0^{\circ} \mathrm{C}$. This is explained by effective protection against 


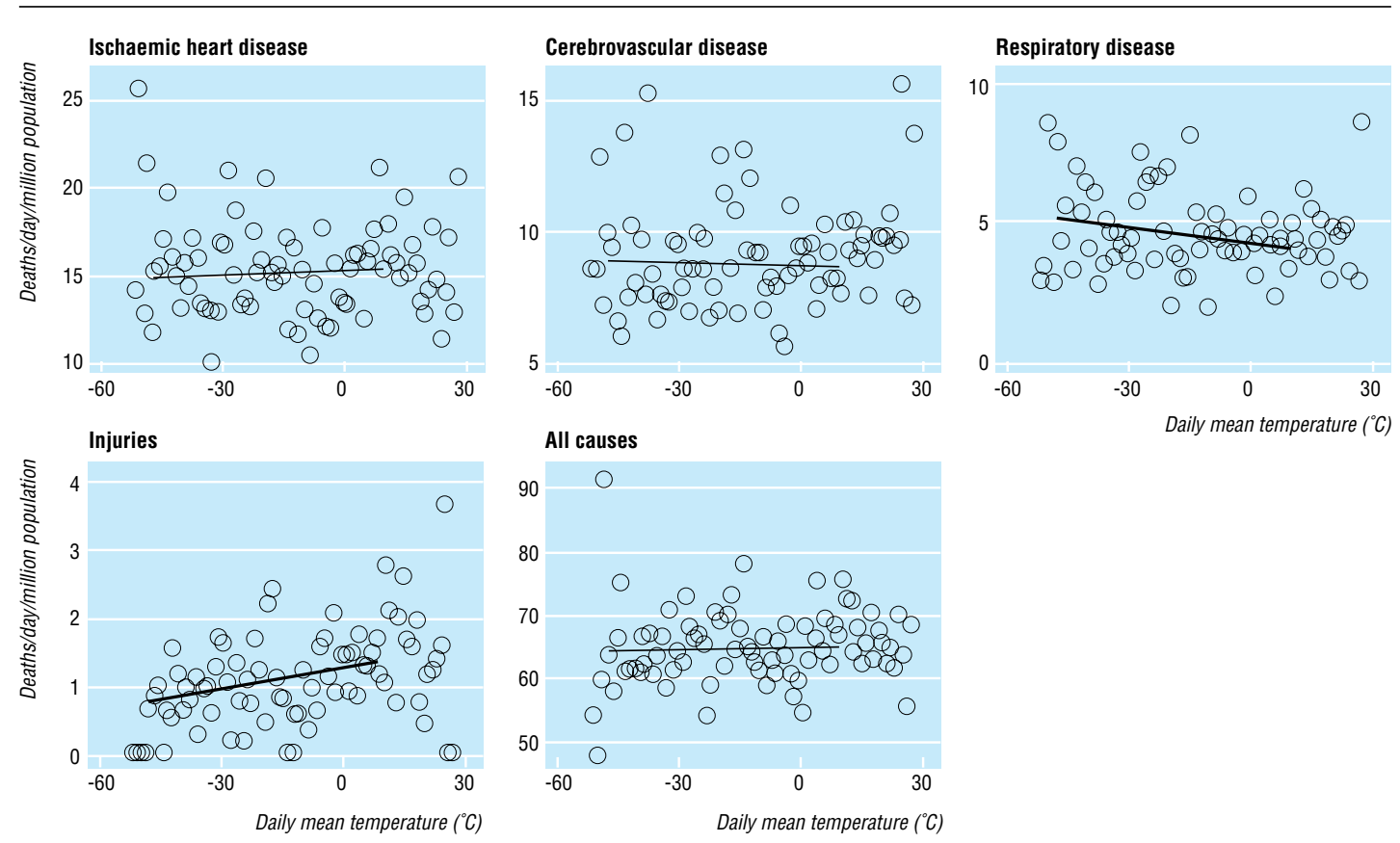

Fig 4 Regression analysis of daily numbers of deaths from ischaemic heart disease, cerebrovascular disease, respiratory disease, injuries, and all causes per million population aged $50-59$ and $65-74$ by mean daily temperature (range $10.2^{\circ} \mathrm{C}$ to $-48.2^{\circ} \mathrm{C}$ ). Thick lines indicate $\mathrm{P}<0.05$, thin lines $\mathrm{P}>0.05$

general cold stress outdoors and warm housing in Yakutsk. Genetic or lifetime adaptations to cold cannot be excluded by our results, although judging from reported shivering apart from cooling of the face and airways the population seems to have had little exposure to cold that could produce such adaptation.

Cooling of the respiratory tract by breathing air at temperatures down to $-48.2^{\circ} \mathrm{C}$ may have contributed to respiratory mortality, which rose as temperature fell. Breathing air at $10^{\circ} \mathrm{C}$ during exercise and at $-17^{\circ} \mathrm{C}$ when resting can trigger bronchospasm in sensitive people through reflexes from cold receptors in the face and upper airways. ${ }^{17}{ }^{18}$ Local cooling may also impair the ability of bronchi to resist infection. Bronchi can cool to below $28^{\circ} \mathrm{C}$ while breathing air at $-18.8^{\circ} \mathrm{C}$ at

\section{Key messages}

- Death rates from ischaemic heart, cerebrovascular, and respiratory disease and all causes have been shown to increase as air temperature falls

- In Yakutsk, Russia, mortality from cerebrovascular and ischaemic heart disease and all causes among people aged 50-59 and 65-74 was unchanged as temperature fell to $-48.2^{\circ} \mathrm{C}$

- Mortality from respiratory disease increased as temperatures fell below $-20^{\circ} \mathrm{C}$ but this was more than offset by a decrease in deaths from accidents

- Exceptionally warm clothing, with reduction of outdoor excursions at temperatures below $-20^{\circ} \mathrm{C}$, prevented overall outdoor cold stress
$60 \mathrm{l} / \mathrm{min}^{19}$ and such cooling slows ciliary movement and induces local inflammatory responses. ${ }^{20} 21$

Our results show that a combination of warm clothing and warm housing can eliminate overall cold related mortality at outdoor temperatures down to $-20^{\circ} \mathrm{C}$ despite a sustained high level of outdoor excursions. If such excursions are restricted at temperatures below $-20^{\circ} \mathrm{C}$ these measures can prevent excess mortality down to $-48.2^{\circ} \mathrm{C}$. Temperatures below $-20^{\circ} \mathrm{C}$ are rare in Europe and other heavily populated regions. Our results support the view that the high winter mortality in such regions is largely preventable by warm clothing and housing. They also suggest that additional measures to prevent cooling of the respiratory tract, and possibly to prevent spread of infection during crowding indoors, may be needed to prevent all excess respiratory mortality in the coldest weather.

We thank the Russian section, Queen Mary and Westfield College, and particularly Dr Anna Pilkington, for help with language and communications in the Russian Federation.

Contributors: GCD analysed the data and contributed to designing the study and writing the paper. YMK and SPE collected and collated the mortality data and participated in consultations on the design of the study and editing of the paper. $\mathrm{CPMcD}$ commissioned the field survey. WRK initiated the study design, drafted the paper, and is guarantor for the study.

Funding: Wellcome Trust

Conflict of interest: None.

1 Eurowinter Group. Cold exposure and winter mortality from ischaemic heart disease, cerebrovascular disease, respiratory disease, and all causes, in warm and cold regions of Europe. Lancet 1997:349:1341-6.

2 Bull GM, Morton J. Environment, temperature and death rates. Age Ageing 1978;7:210-24.

3 Frost DB, Auliciems A, de Freitas C. Myocardial infarct death and temperature in Auckland, New Zealand. Int J Biometeorol 1992;36:14-7.

4 Heunis JC, Olivier J, Bourne DE. Short-term relationships between winter temperatures and cardiac disease mortality in Cape Town. South African Med J 1995;85:1016-9. 
5 Donaldson GC, Tchernjavskii VE, Ermakov SP, Bucher K, Keatinge WR. Winter mortality and cold stress in Yekaterinburg, Russia: interview study. BMJ 1998;316:514-8.

6 Donaldson GC, Keatinge WR. Early increases in ischaemic heart disease mortality dissociated from, and later changes associated with, respiratory mortality, after cold weat Health 1997:51:643-8.

7 Keatinge WR, Coleshaw SRK, Cotter F, Mattock M, Murphy M, Chelliah R. Increases in platelet and red cell counts, blood viscosity, and arterial pressure during mild surface cooling: factors in mortality from coronary and cerebral thrombosis in winter. BMJ 1984;289:1405-8.

8 Neild PJ, Syndercombe-Court D, Keatinge WR, Donaldson GC, Mattock M, Caunce M. Cold-induced increases in erythrocyte count, plasma cholesterol and plasma fibrinogen of elderly people without a comparable rise in protein C or factor X. Clin Sci 1994;86:43-8.

9 Woodhouse PR, Khaw K-T, Plummer M, Foley A, Meade TW. Seasonal variations of plasma fibrinogen and factor VII activity in the elderly: winter infections and death from cardiovascular disease. Lancet 1994;343: $435-9$

10 Collins KJ, Easton JC, Belfield-Smith H, Exton-Smith AN, Pluck RA. Effects of age on body temperature and blood pressure in cold environments. Clin Sci 1985;69:465-70.

11 Farb A, Tang AL, Burke AP, Sessums L, Liang Y, Virmani R. Sudden coronary death: frequency of active coronary lesions, inactive coronary lesions, and myocardial infarction. Circulation 1995;92:1701-9

12 Giesbrecht GG. The respiratory system in a cold environment. Aviat Space Environ Med 1995;66:890-902.

13 Lewis C, Campbell JD. Oxford atlas. Oxford: Oxford University Press, 1970:11.
14 Gray, PG, Corlett, T Sampling for the social survey. Journal of the Royal Statistical Society 1950;113[A]:150-99.

15 Hayward MG, Keatinge WR. Roles of subcutaneous fat and thermoregulatory reflexes in determining ability to stabilize body temperature in water.J Physiol 1981;320:229-51.

16 Lovett AA, Bentham CG, Flowerdew R. Analysing geographical variations in mortality using Poisson regression: the example of ischaemic heart disease in England and Wales 1969-1973. Soc Sci Med 1986;23:935-43.

17 Eschenbacher WL, Moore TB, Lorenzen TJ, Weg JG, Gross KB. Pulmonary responses of asthmatic and normal subjects to different temperature and humidity conditions in an environmental chamber. Lung 1992;170:51-62.

18 Koskela H, Tukiainen H. Facial cooling but not breathing of cold air induces bronchoconstriction: a study in asthmatic and healthy subjects. Eur Respir J 1995;8:2088-93.

19 McFadden ER, Pichurko BM, Bowman HF, Ingenito E, Burns S, Dowling N, et al. Thermal mapping of the airways in humans. J Appl Physiol 1985;58:564-70.

20 Hill L. The ciliary movement of the trachea studied in vitro. A measure of toxicity. Lancet 1928;i:802-5.

21 Yoshihara S, Chan B, Yamawaki I, Gepetti P, Ricciadolo FL, Massion PP, et al. Plasma extravasation in the rat trachea induced by cold air is mediated by tachykinin release from sensory nerves. Am J Respir Crit Care Med 1995; 151:1011-7.

(Accepted 26 June 1998)

\section{Severe deep white matter lesions and outcome in elderly patients with major depressive disorder: follow up study}

John O’Brien, David Ames, Edmond Chiu, Isaac Schweitzer, Patricia Desmond, Brian Tress

Department of

Psychiatry and

Institute for the

Health of the

Elderly, University

of Newcastle upon

Tyne, Newcastle

General Hospital,

Newcastle upon

Tyne NE4 6BE

John O'Brien,

senior lecturer in old

age psychiatry

University of

Melbourne

Department of

Psychiatry, Royal

Melbourne

Hospital, Parkville,

Victoria 3050,

Australia

David Ames,

associate professor of

psychiatry of old age

Edmond Chiu,

associate professor of

psychiatry of old age

Isaac Schweitzer,

associate professor of

psychiatry

Department of

Radiology, Royal

Melbourne

Hospital, Australia

Patricia Desmond,

radiologist

Brian Tress,

professor of radiology

Correspondence to Dr O'Brien

j.t.o'brien@ncl.ac.uk

BMJ 1998;317:982-4

\section{Abstract}

Objective To determine the difference in outcome among elderly people with major depression who do and do not have severe white matter lesions on magnetic resonance imaging.

Design Follow up study.

Setting Two psychiatric and two general hospitals in Melbourne, Australia.

Subjects 60 depressed subjects aged over 55 referred to hospital psychiatric services with major depressive disorder meeting American Psychiatric Association

(DSM-IIIR) criteria.

Main outcome measure Proportion with good outcome as determined by full recovery from initial illness and no evidence of depressive relapse or cognitive decline during follow up among those with and without lesions.

Results Mean (SD) follow up was 31.9 (9.9) months. Survival analysis showed a significant effect of severe lesions on time to poor outcome $(\mathrm{P}=0.04)$, with median survival 136 days in those with severe lesions compared with 315 days in those without.

Conclusion Severe white matter change on magnetic resonance imaging is associated with poor outcome in elderly depressed subjects.

\section{Introduction}

Major depressive disorder ${ }^{1}$ in older people often has a poor prognosis. ${ }^{2}$ Cerebral organic factors may predict poor outcome. ${ }^{2}{ }^{3}$ Recent studies of the brains of elderly depressed patients have reported an excess of deep white matter lesions (but not periventricular lesions) on magnetic resonance imaging. Mild and moderate white matter lesions are common in healthy elderly people and of uncertain significance. However, severe changes are not part of normal ageing, although they are often seen in elderly depressed subjects. ${ }^{4}$ Such severe white matter lesions may predispose to the onset of first depression in some elderly people ${ }^{4}$ and have been reported to be associated with poor response to initial treatment. ${ }^{56}$ It is not known, however, whether white matter lesions have any influence on long term outcome in major depressive disorder. We report a follow up study of 54 elderly subjects with major depressive disorder, all of whom had magnetic resonance imaging at baseline to determine the presence and severity of deep white matter and periventricular lesions.

\section{Subjects and methods}

A more detailed account of subject selection and scanning procedure has been published. ${ }^{4}$ In brief, 60 consecutive patients aged over 55 who met the Diagnostic and Statistical Manual of Mental Disorders (DSM-IIIR) criteria for major depressive disorder were recruited from two general and two old age psychiatric units in Melbourne over 18 months in 1992-3. All consented to magnetic resonance imaging and had a full psychiatric assessment including physical examination and screening blood tests (routine haematology and biochemical analyses including tests of thyroid function). Severity of depression was assessed with the Hamilton depression rating scale $^{7}$ and cognitive function with the Cambridge cognitive examination, ${ }^{8}$ which includes the mini-mental state examination. Subjects were excluded if they had a history of stroke, 